\title{
CrimRxiv
}

\section{CACC: Conjunctive Analysis of Case Configurations}

Miriam Esteve, Asier Moneva, Timothy Hart

Published on: Jun 29, 2021

DOI: $10.21428 / \mathrm{cb} 6 \mathrm{ab} 371.11 \mathrm{~d} 9663 \mathrm{f}$

License: Creative Commons Attribution 4.0 International License (CC-BY 4.0). 
